\title{
PENGERTIAN, TUJUAN DAN RUANG LINGKUP STRATEGI PEMBELAJARAN
}

\author{
Mohammad Asrori ${ }^{1}$
}

\begin{abstract}
Abstarak
Untuk menghasilkan pendidikan yang baik, tentunya harus memiliki strategi dalam proses belajar mengajar (pembelajaran). Oleh karena itu penetapan strategi yang relevan merupakan suatu keharusan. Strategi pembelajaran yang tepat akan membina peserta didik (mahasiswa) untuk berfikir mandiri, kreatif dan sekaligus adaptif terhadap berbagai situasi yang terjadi dan yang mungkin terjadi. Karena penetapan strategi yang tidak tepat akan berakibat fatal. Sebab akan terjadi kontraproduktif dan berlawanan dengan apa yang ingin dicapai, misalnya seorang dosen mengajar agar mahasiswa menjadi kreatif, akan tetapi mengajar dengan cara-cara otoriter dan kaku. Maka dalam hal ini yang akan mengakibatkan kefatalan terhadap mahasiwa tersebut.
\end{abstract}

Key Word: Pengertian, Tujuan, Ruang Lingkup, Strategi Pembelajaran

\section{A. Pendahuluan}

Membicarakan masalah pendidikan, sudah barang tentu akan melibatkan banyak hal yang harus direnungkan. Sebab, pendidikan meliputi keseluruhan tingkah laku manusia yang dilakukan demi memperoleh kesinambungan, pertahanan dan peningkatan hidup.

Untuk menghasilkan pendidikan yang baik, tentunya harus memiliki strategi dalam proses belajar mengajar (pembelajaran). Oleh karena itu penetapan strategi yang relevan merupakan suatu keharusan. Strategi pembelajaran yang tepat akan membina peserta didik (mahasiswa) untuk berfikir mandiri, kreatif dan sekaligus adaptif terhadap berbagai situasi yang terjadi dan yang mungkin terjadi. Karena penetapan strategi yang tidak tepat akan berakibat fatal. Sebab akan terjadi kontraproduktif dan berlawanan dengan apa yang ingin dicapai, misalnya seorang dosen mengajar agar mahasiswa menjadi kreatif, akan tetapi mengajar dengan cara-cara otoriter dan kaku. Maka dalam hal ini yang akan mengakibatkan kefatalan terhadap mahasiwa tersebut.

1 Dosen Fakultas Ilmu Tarbiyah Dan Keguruan Universitas Islam Negeri Maulana Malik Ibrahim Malang Jl. Gajayana No. 50 Malang 65144 
Dalam hal ini juga dikatakan, pengetahuan dan teori bagaimana berlari yang baik tentu saja akan menambah pemahaman seseorang tentang hal-ihwal berlari. Akan tetapi tori-teori tersebut tidak dapat membuat ia menjadi pelari yang baik apabila ia mencukupkan pada teori itu saja. Untuk mencapai hasil yang optimal, ia harus mendapatkan kesempatan guna mengaplikasikan teori-teori tersebut dan berlatih berlari tahap demi tahap dengan perbaikan-perbaikan seperlunya. Hal yang sama juga berlaku untuk pembelajaran yang lain, seperti kemampuan berpikir, keterampilan bergaul dan manajemen. (Mansyur, 1991: 6)

Dengan demikian, cara mengajar yang seperti ini bisa berlangsung apabila peserta didik (mahasiswa) secara leluasa dapat melatih kemampuannya dalam berbagai bentuk kegiatan. Proses pembelajaran yang berlangsung di dalam kelas diharapkan mampu mem bantu proses belajar peserta didik dan merangsang serta mendorong mereka untuk secara mandiri aktif melakukan sesuatu. Oleh karena itu, ketika mempersiapkan perkuliahan, guru atau dosen harus memikirkan cara agar peserta didik (mahasiswa) memproses informasi yang disampaikan. Di sisi lain, guru atau dosen juga harus mempertimbangkan cara mengaitkan informasi yang disampaikan dengan pengetahuan yang dimiliki sebelumnya oleh peserta didik (mahasiswa)-(piror knowledge)-. Dengan demikian, seluruh rangkaian proses pembelajaran mulai dari mendengar, beraktivitas dan berdiskusi diharapkan menjadi pengalaman yang berkesan kuat dan bermanfaat bagi peserta didik (mahasiswa).

\section{B. Pengertian}

\section{Pengertian Strategi Secara Umum dan Khusus}

Istilah Strategi mula-mula dipakai di kalangan militer dan diartikan sebagai seni dalam merancang (operasi) peperangan, terutama yang erat kaitannya dengan gerakan pasukan dan navigasi ke dalam polisi perang yang dipandang paling menguntungkan untuk memperoleh kemenangan. Penetapan strategi tersebut harus didahului oleh analisis kekuatan musuh yang meliputi jumlah personal, kekuatan senjata, kondisi lapangan, posisi musuh, dan sebagainya. Dalam perwujudannya, strategi tersebut akan dikembangkan dan dijabarkan lebih lanjut menjadi tindakan- tindakan nyata dalam medan pertempuran. (Abu Ahmadi, dan Joko Tri Prasetya, 1997: 11) 
Istilah strategi dewasa ini banyak dipakai oleh bidang-bidang ilmu lainnya, termasuk juga dalam dunia pendidikan. Secara umum strategi mempunyai pengertian sebagai suatu garis besar haluan dalam bertindak untuk mencapai sasaran yang telah ditentukan. Kemudian jika dihubungkan dengan kegiatan belajar mengajar, maka strategi dalam artian khusus bisa diartikan sebagai pola umum kegiatan yang dilakukan guru-murid dalam suatu perwujudan kegiatan belajar mengajar untuk mencapai tujuan yang telah digariskan. (Abu Ahmadi, dan Joko Tri Prasetya, 1997: 12)

Dalam pemilihan strategi haruslah dipilih strategi yang tepat, pengajaran yang diberikan kepada anak didik tidak bersifat paksaan bahkan perilaku pemimpin kadang tidak perlu dilakukan. Sebagai gantinya, para pendidik harus bersikap ngemong atau among. Para guru seharusnya tidak mengajarkan pengetahuan mengenai dunia secara dogmatik. Sebaliknya mereka hanya berada dibelakang anak didik sambil memberi dorongan untuk manju, secara khusus mengarahkan ke jalan yang benar, dan mengawasi kalau-kalau anak didik menghadapi bahaya atau rintangan. Anak didik harus memiliki kebebasan untuk maju menurut karakter masing-masing dan untuk mengasah hati nuraninya. Dengan demikian tugas pendidik adalah memikirkan dan memilih strategi yang sesuai dengan tujuan pembelajaran serta karakteristik anak didiknya.

Tujuan pembelajaran yang telah dirumuskan akan dapat tercapai secara berdaya guna dan berhasil guna, maka guru dituntut untuk memiliki kemampuan mengatur secara umum komponen-komponen pembelajaran sedemikian rupa sehingga terjalin keterkaitan fungsi antara komponen pembelajaran yang dimaksud.

Untuk melaksanakan tugas secara profesional guru diharuskan memiliki wawasan yang mantap tetang strategi pembelajaran yang sesuai dengan tujuan belajar atau tujuan pembelajaran yang telah dirumuskan, baik dalam arti efek instruksional (tujuan yang telah dirumuskan secara eksplisit) maupun dalam arti efek pengiring (hasil yang didapat dalam proses pembelajaran), misalnya: kemampuan berfikir kritis, kreatif, terbuka, dll. (M. Asrorun Ni'am, 2006: 3)

\section{Pengertian dan Tujuan Pembelajaran (Learning Objectives)}

Kata pembelajaran sengaja dipakai sebagai padanan kata yang berasal dari bahasa Inggris Instruction. Kata Instruction mempunyai 
pengertian yang lebih luas daripada pengajaran. Jika kata pengajaran ada dalam konteks guru-murid di kelas (ruang) formal, pembelajaran atau Instruction mencakup pula kegiatan belajar mengajar yang tak dihadiri guru secara fisik. Oleh karena dalam Instruction yang ditekankan adalah proses belajar, maka usaha-usaha yang terencana dalam manipulasi sumber-sumber belajar agar terjadi proses belajar dalam diri siswa kita sebut pembelajaran. (Arief S. Sadirman, 1996: 7)

Learning Objectives (LO) adalah istilah yang menggabungkan (compounding) dua kata, yaitu kata Learning yang berarti "belajar" atau pembelajaran dan kata Objectives yang berarti "tujuan". Secara harfiah LO itu berarti tujuan belajar, sedangkan menurut istilah adalah sebagai berikut:

Cranton mengemukakan bahwa tujuan pembelajaran adalah pernyataan-pernyataan tentang pengetahuan dan kemampuan yang diharapkan dari peserta setelah selesai pembelajaran (Cranton, 1989). Sementara itu, Meger dalam bukunya yang berjudul Preparing Instructional Objetives (1975), menyatakan bahwa tujuan pembelajaran adalah gambaran kemampuan mahasiswa yang menunjukkan kinerja yang diinginkan yang sebelumnya mereka tidak mampu.

Di samping tersebut di atas, ada juga yang mengemukakan bahwa tujuan pembelajaran adalah Learning Objectives are statement articulating the learning your will achieve in your cours (Lihat Hand Out Workshop Sistem Pendidikan, 1996). Artinya bahwa tujuan pembelajaran ialah pernyataan-pernyataan yang menyatakan hasil belajar yang akan dicapai oleh mahasiswa pada mata kuliah anda. (Hisyam Zaini, 2002: 57)

Ada beberapa istilah semakna dengan Learning Objectives (LO), di antaranya adalah Learning Outcomes dan Tujuan Intruksional. Istilah yang populer digunakan di Indonesia adalah tujuan instruksional. Adapun tujuan intruksional dibagi menjadi dua, yaitu: (1) tujuan intruksional umum (TIU), yaitu pernyataan yang menggambarkan kemampuan umum yang seharusnya dicapai oleh mahasiswa setelah menyelesaikan satu bidang studi atau mata kuliah selama satu semester. (2) tujuan intruksional khusus (TIK), yaitu tujuan yang menggambarkan hasil belajar yang harus dicapai oleh mahasiswa setelah tatap muka dengan satu pokok bahasan atau topik pelajaran tertentu. (Hisyam Zaini, 2002: 58) 
Namun pembahasan kali ini, penekanan istilah yang digunakan adalah Learning Objectives (LO), yaitu pernyataan-pernyataan yang menggambarkan hasil belajar yang akan dicapai oleh mahasiswa setelah melalui proses pembelajaran satu semester. Meskipun LO dibuat untuk satu semester, tetapi tidak berarti pernyataan-pernyataan itu dibuat bersifat general (tidak operasioanal), sebagaimana yang terdapat dalam TIU atau TPU. LO harus tetap spesifik (operasional), akan tetapi, sifat spisifik itu tidaklah berarti seperti apa yang ada dalam TIK atau TPK yang hanya menggambarkan tujuan untuk satu kali tatap muka. Satu hal yang juga harus diperhatikan bahwa LO itu seyogianya bersifat content-free, maksudnya dalam menyusun LO jangan hanya mengambil dari topik materi yang ada dalam silabus yang mencakup pokok bahasa satu kali tatap muka. Contoh LO (Tujuan Pembelajaran) yang berorientasi kepada konten adalah sebagai berikut:

a. Mahasiswa mampu mengidentifikasi bagian-bagian dari hati.

b. Mahasiswa mampu mengidentifikasi bagian-bagian dari paruparu.

c. Mahasiswa mampu menggambarkan fungsi-fungsi hati.

d. Mahasiswa mampu menggambarkan fungsi paru-paru.

Keempat LO di atas dapat diformulasikan menjadi dua hal LO yang lebih general, yaitu sebagai berikut:

a. Mahasiwa mampu mengidentifikasi bagian-bagian dari sebuah struktur yang diberikan.

b. Mahasiswa mampu menggambarkan fungsi-fungsi dari struktur yang diberikan.

Dari dua pernyataan tersebut menggambarkan dengan jelas tetang tipe kinerja yang harus didemonstrasikan oleh mahasiswa. Namun, ia tidak terkait secara langsung dengan bagian-bagian tubuh tertentu, seperti pada empat contoh sebelumnya. Keuntungan dari pernyataan bebas materi (content-free) yaitu dapat digunakan untuk beberapa unit pembelajaran. (Hisyam Zaini, 2002: 59)

\section{Pengertian Strategi Pembelajaran}

Dalam proses belajar-mengajar, guru harus memiliki strategi, agar siswa dapat belajar secara efektif dan efesien. Salah satu langkah untuk 
memiliki strategi itu ialah harus menguasai teknik-teknik penyajian, atau biasanya disebut metode mengajar.

Belajar mengajar adalah suatu kegiatan yang bersifat edukatif. Nilai edukatif mewarnai interaksi yang terjadi antar guru dan anak didik. Interaksi yang bersifat edukatif dikarenakan kegiatan belajar mengajar yang dilakukan, diarahkan untuk mencapai tujuan tertentu yang telah dirumuskan sebelum pengajaraan dilakukan. Guru dengan sadar merencanakan kegiatan pengajaran secara sistematis dengan memanfaatkan segala sesuatu guna kepentingan pengajaraan.

Dalam kamus ilmiah populer strategi mempunyai arti ilmu siasat atau muslihat untuk mencapai suatu tujuan. (Pius A Partaaanto dan M. Dahlan Al Barry, 2001: 727) Secara umum strategi mempunyai pengertian suatu garis-garis besar haluan untuk bertindak dalam usaha mencapai tujuan atau sasaran yang ditentukan. (Syaiful Bahri Jamrah dan Aswan Zain, 1996: 5) Dihubungkan dengan proses pembelajaran, strategi biasa diartikan sebagai siasat atau pola-pola umum kegiatan guru dan anak didik dalam perwujudan kegiaatan belajar mengajar untuk mencapai tujuan yang telah ditetapkaan.

Mc. Leod mengatakan bahwa secara harfiah dalam bahasa Inggris kata "strategi" dapat diartikan sebagai seni (art) melakasanakan strategem yakni siasat atau rencana. (Muhibbin Syah, 2003: 214) Istilah startegi sering digunakan dalam banyak konteks dengan makna yang tidak sama. Dalam kontek pembelajaran, Nana Sudjana juga mengatakan bahwa strategi mengajar adalah " taktik" yang digunakan guru dalam melaksanakan proses belajar mengajar (pembelajaran) agar dapat mempengaruhi siswa (peserta didik) untuk mencapai tujuan pembelajaran (TIK) secara efektif dan efesien. (Ahmad Rohani dan Abu Ahmadi, 133)

Hilda Taba menyatakan bahwa strategi pembelajaran adalah caracara yang dipilih oleh guru dalam proses pembelajaran yang dapat memberikan kemudahan dan fasilitas bagi siswa menuju tercapainya tujuan pembelajaran. (Supriadi Saputro, 2000: 21)

Sedangkan menurut Slameto strategi adalah suatu rencana tentang cara-cara pendayagunaan dan penggunaan potensi dan sasaran yang ada untuk mreningkatkan efektivitas dan efesiensi dalam kontek ini adalah pembelajaran. (Slameto, 1991: 90)

Strategi Pembelajaran merupakan garis besar haluan bertindak untuk mencapai tujuan yang telah ditetapkan, dalam arti ilmu dan kiat 
didalam memanfaatkan segala sumber yang dimiliki dan/atau yang dapat dipakai untuk mencapai tujuan yang telah ditetapkan.

Strategi Pembelajaran adalah metode dalam arti luas yang mencakup perencanaan, pelaksanaan, penilaian, pengayaan, dan remedial yaitu memilih dan menentukan perubahan perilaku, pendekatan prosedur, metode, teknik, dan norma-norma atau batas-batas keberhasilan

\section{Unsur-Unsur Strategi Pembelajaran}

Agar dapat merancang serta melaksanakan strategi pembelajaran yang efektif perlu memperhatikan unsur-unsur strategi dasar atau tahapan langkah sebagai berikut:

1. Menetapkan spesifikasi dari kualifikasi perubahan perilaku, tujuan selalu dijadikan acuan dasar dalam merancang dan melaksanakan setiap kegiatan pembelajaran. Oleh sebab itu tujuan pembelajaran harus dirumuskan secara spesifik dalam arti mengarah kepada perubahan perilaku tertentu dan operasional dalam arti dapat diukur.

2. Memilih pendekatan pembelajar, suatu cara pandang dalam menyampaikan yang telah direncanakan untuk mencapai tujuan yang telah ditetapkan. Dalam melaksanakan kegiatan pembelajaran harus dipertimbang dan dipilih jalan pendekatan utama yang dipandang paling ampuh, paling tepat, dan paling efektif guna mencapai tujuan.

3. Memilih dan menetapkan metode, teknik, dan prosedur pembelajaran.

(1) Metode merupakan cara yang dipilih untuk menyampaikan bahan sesuai dengan tujuan pembelajaran (2) Teknik merupakan cara untuk melaksanakan metode dengan sarana penunjang pembelajaran yang telah ditetapkan dengan memperhatikan kecepatan dan ketepatan belajar untuk mencapai tujuan (3) Merancang Penilaian (4) Merancang Remedial (5) Merancang Pengayaan. 


\section{Macam-Macam Strategi.}

Secara umum strategi pembelajaran dibagi menjadi tiga:

1). Strategi Indukatif adalah suatu strategi pembelajaran yang memulai dari hal-hal yang khusus barulah menuju hal yang umum.

2). Strategi Dedukatif adalah suatu strategi pembelajaran yang umum menuju hal-hal yang khusus

3). Strategi campuran adalah gabungan dari strategi indukatif dan dedukatif. Adapula strategi regresif yaitu strategi pembelajaran yang memakai titik tolak jaman sekarang untuk kemudian menelusuri balik (kebelakang) ke masa lampau yang merupakan latar belakang dari perkembangan kontemporer tersebut.

Menurut Gagne mengemukakan ada lima pendekatan yang diistilahkan dengan proses atau jalur belajar yaitu: 1. informasi verbal, 2. kemahiran intlektual, 3. pengaturan kegiatan kognitif, 4. keterampilan motorik dan 5. sikap. Sedang merumuskan tujuan pembelajaran Gagne tetap berpedoman dengan taksonomi Bloom dan kawan-kawan dengan 3 ranah perwujudan pembelajaran menurut Gagne pada Tabel.

\begin{tabular}{|c|c|c|c|c|c|}
\hline \multicolumn{2}{|c|}{ Ranah Kognitif } & \multicolumn{2}{|l|}{ Ranah Afektif } & \multicolumn{2}{|c|}{ Ranah Psikomotorik } \\
\hline Bloom & Gagne & Bloom & Gagne & Bloom & Gagne \\
\hline Pengetahuan & \begin{tabular}{|l} 
Informasi \\
Verbal
\end{tabular} & $\begin{array}{l}\text { 1. Penerimaan } \\
\text { 2. Pertisipasi } \\
\text { 3. Penilaian dan } \\
\text { penemuam sikap } \\
\text { 4. Organisasi } \\
\text { 5. Pembentukan } \\
\text { 6. Pola hidup }\end{array}$ & Sikap & $\begin{array}{l}\text { 1. Persepsi } \\
\text { 2. Persiapan } \\
\text { 3. Gerakan } \\
\text { terbimbing } \\
\text { 4. Gerakan yang } \\
\text { terbiasa } \\
\text { 5. Gerakan yang } \\
\text { kompleks } \\
\text { 6. Penyesuaian } \\
\text { 7. } \text { Kreativitas }\end{array}$ & $\begin{array}{l}\text { Keterampilan } \\
\text { motorik }\end{array}$ \\
\hline
\end{tabular}

\section{Ruang Lingkup Strategi Pembelajaran}

Strategi pembelajaran aktualisasinya berwujud serangkaian dari keseluruhan tindakan strategis guru dalam rangka mewujudkan kegiatan pembelajaran yang efektif dan efisien. Efektifitas Strategi dapat diukur dari tingginya kuantitas dan kualitas hasil belajar yang dicapai anak. Sedangkan efisien dalam arti penggunaan Strategi yang dimaksud 
sesuai dengan waktu, fasilitas, maupun kemampuan yang tersedia.

Secara singkat, menurut Slameto strategi pembelajaran mencakup 8 unsur perencanaan tentang:

1. Komponen sistem yaitu guru/dosen, siswa/mahasiswa baikdalam ikatan kelas, kelompok maupun perorangan yang akan terlibat dalam kegiatan belajar mengajar telah disiapkan,

2. Jadwal pelaksanaan, format dan lama kegiatan telah disiapkan,

3. Tugas-tugas belajar yang akan dipelajari dan yang telah diidentifikasikan,

4. Materi/bahan belajar, alat pelajarandan alat bantu mengajar yang disiapkan dan diatur,

5. Masukan dan karakteristik siswa yang telah diidentifikasikan,

6. Bahan pengait yang telah direncanakan,

7. Metode dan teknik penyajian telah dipilih, misalnya ceramah, diskusi dan lain sebagainya, dan

8. Media yang akan digunakan. (Slameto, 1991: 91-92)

Keseluruhan tindakan strategis guru dalam upaya merealisasikan kegiatan pembelajaran, mencakup dimensi yang bersifat makro (umum) maupun bersifat mikro (khusus).

Secara makro, strategi pembelajaran berkait dengan tindakan strategis guru dalam: (a) memilih dan mengoperasionalkan tujuan pembelajaran (b) memilih dan menetapkan setting pembelajaran (c) pengelolaan bahan ajar $(\mathrm{d})$ pengalokasian waktu (e) pengaturan bentuk aklivitas pembelajaran (f) metode teknik dan prosedur pembelajaran (g) pemanfaatan penggunaan media pembelajaran (h) penerapan prinsip-prinsip pembelajaran (i) penerapan pendekatan pola aktivitas pembelajaran (j) pengemabangan iklim pembelajaran (k) pemilihan pengembangan dan pelaksanaan evaluasi. (Supriadi Saputro, 2000: 23-24)

Bertolak dari jabaran tentang tindakan strategis guru tersebut di atas, kiranya dapat dimengerti bahwa secara makro, strategi pembelajaran berhubungan dengan pembinaan dan pengembangan program pembelajaran. Oleh karena itu, strategi pembelajaran mengaktual pada strategi perencanaan, pelaksanaan dan strategi penilaian pembelajaran. 
Sedangkan tindakan guru yang bersifat mikro, berkaitan langsung dengan tindakan-tindakan operasional-interaktif guru di kelas.

Tindakan guru yang dimaksud berhubungan dengan pelaksanaan siasat dan taktik dalam mengoperasionalkan pelaksanaan metode, teknik, prosedur pembelajaran maupun siasat dan taktik operasional dalam penggunaan media dan sumber pembelajaran.

\section{Klasifikasi Belajar Mengajar}

Menurut Tabrani dkk. dalam Syaiful Bahri Djamarah dan Aswan Zain menyatakan bahwa terdapat berbagai masalah sehubungan dengan strategi belajar mengajar yang secara keseluruhan diklasiflkasikan seperti berikut:

\section{a. Konsep dasar belajar mengajar}

Konsep dasar strategi belajar mengajar meliputi:

1) Menetapkan spesifikasi dan kualifikasi perubahan tingkah laku,

2) Menentukan pilihan berkenaan dengan pendekatan terhadap masalah belajar mengajar,

3) Memilih prosedur, metode dan teknik belajar mengajar, dan

4) Menerapkan norma dan kriteria keberhasilan kegiatan belajar mengajar

\section{b. Sasaran kegiatan belajar mengajar}

Setiap kegiatan belajar mengajar mempunyai sasaran atau tujuan. Tujuan itu bertahap dan berjenjang mulai dari yang sangat operasional dan konkret. Persepsi guru atau persepsi anak didik mengenai sasaran akliir kegiatan belajar mengajar akan mempengaruhi persepsi mereka terhadap sasaran-antara serta sasaran-kegiatan. Sasaran itu harus diterjemahkan ke dalam ciri-ciri perilaku kepribadian yang didambakan.

\section{c. Belajar mengajar sebagai suatu sistem}

Belajar mengajar sebagai suatu sistem mengacu pengertian sebagai seperangkat komponen yang sal ing bergantung satu sama lain untuk mencapai tujuan. Selaku suatu sistem, belajar mengajar meliputi suatu 
komponen antara lain tujuan, bahan, siswa, guru, metode, situasi dan evaluasi. Agar tujuan tercapai, maka semua komponen yang ada harus diorganisasikan sehingga antar sesama komponen terjadi kerja sama. Karena itu guru tidak boleh hanya memperhatikan komponen tertentu saja, tetapi harus mempertimbangkan komponen secara keseluruhan.

\section{d. Hakikat proses belajar}

Belajar proses perubahan perilaku berkat pengalaman dan latihan. Artinya, tujuan kegiatan adalah perubahan tingkah laku, baik yang menyangkut pengetahuan, ketrampilan maupun sikap, bahkan meliputi segenap aspek organisme atau pribadi. Kegiatan belajar mengajar seperti mengorganisasi pengalaman belajar, mengolah kegiatan belajar mengajar, menilai proses dan hasil belajar, kesemuanya termasuk dalam oakupan tanggung jawab guru.

\section{e. Entering behavior siswa}

Hasil kegiatan belajar mengajar tercermin dalam perubahan perilaku, baik secara material-substansional, struktural-fungsional, maupun secara behavior. Yang dipersoalkan adalah kepastian bahwa tingkat prestasi yang dicapai siswa itu apakah benar merupakan kegiatan belaja mengajar yang bersangkutan. Untuk kepastiannya seharusnya guru mengetahui tentang karakteristik perilaku anak didik saat mereka mau masuk sekolah dan mulai dengan kegiatan belajar mengajar dilangsungkan, tingkat dan jenis karakteristik perilaku anak didik yang telah dimilikinya ketika mau mengikuti kegiatan belajar mengajar. Itulah yarig dimaksud dengan entering behavior siswa.

Menurut Abin Syamsuddin, Entering Behavior akan dapat diidentifikasi dengan cara:

1. Secara tradisional, telah lazim para guru mulai dengan pertanyaan mengenai bahan yang pernah diberikan sebelum menyajikan bahan baru.

2. Secara inovatif, guru tertentu di berbagai lembaga pendidikan yang memiliki atau mampu mengembangkan instrument pengukuran prestasi belajar dengan memenuhi syarat, pengadaan pre-tes sebelum mereka mulai mengikuti program belajar mengajar. 
Mohammad Asrori - Pengertian, Tujuan dan Ruang Lingkup Strategi ...

\section{f. Pola-pola belajar siswa}

Robert M. Gagne membedakan pola belajar siswa ke dalam delapan tipe, di mana yang satu merupakan prasyarat bagi lainnya yang lebih tinggi hirarkinya. Pola-pola itu adalah: 1) Signal Learning (belajar isyarat) 2) Stimulus Response Learning (belajar stimulus-respon) 3) Chaining (rantai atau rangkaian), 4) Verbal Association (asosiasi verbal) 5) Discrimination Learning (belajar kriminasi) 6) Concept Learning (belajar konsep) 7) Rule Learning (belajar aturan) 8) Problem Solving (memecahkan masalah). (Syaiful Bahri Jamrah dan Aswan Zain, 1996: 8-14)

\section{Hubungan Antara Tujuan Strategi Dan Evaluasi}

Komponen-komponen dasar program pembelajaran meliputi: (a) tujuan yang akan dicapai, (b) strategi pembelajaran yang terdiri atas berbagai kegiatan yang berhubungan dengan pelaksanaan metode, teknik, alat, media dan prosedur pembelajaran, dan (c) komponen evaluasi pembelajaran. Berbagai komponen pembelajaran tersebut berkait secara interaktif dan fungsional antara satu derigan yang lain. (Syaiful Bahri Jamrah dan Aswan Zain, 1996: 29)

Keterkaitan fungsional dan timbal balik antara tujuan pembelajaran dengan strategi dapat dijelaskan bahwa, strategi pembelajaran merupakan wahana untuk mencapai tujuan pembelajaran dan sebaliknya tujuan menjadi acuan dalam penentuan strategi. Dikatakan sebagai wahana untuk mencapai tujuan pembelajarann, menginigat tindakan-tindakan strategis guru dalam pelaksanaan pembelajaran tersebut bermaksud untuk mencapai tujuan pembelajaran. Sebagai implikasi dari fakta bahwa strategi pembelajaran tersebut sebagai wahana untuk mencapai tujuan pembelajaran, maka jenis-jenis strategi yang digunakan memerlukan penyesuaian-penyesuaian agar relevan dengan karakteristik tujuan yang akan dicapai. Mengingat hal itu, maka tujuan pembelajaran merupakan acuan dalam perencanaan strategi pembelajaran yang akan digunakan. Sementara itu, hubungan fungsional dan timbal balik antara tujuan pernbelajaran dengan evaluasi adalah bahwa evaluasi adalah alat untuk mengukur ketercapaian tujuan. Dengan evaluasi, dapat diukur kuantitas dan kualitas pencapaian tujuan pembelajaran. Sebaliknya, oleh karena evaluasi sebagai alat ukur ketercapaian tujuan, maka tolok ukur perencanaan dan pengembangannya adalah tujuan pembelajaran. Artinya, perencanaan dan pengembangan 
evaluasi menyesuaikan dengan karakteristik tujuan pembelajaran. Sehubungan dengan itu, maka teknik, substansi, maupun instrument evaluasi yang akan digunakan, perencanaan dan pengembangannya mengacu pada tujuan-tujuan pembelajaran.dengan demikian evaluasi merupakan alat ukur untuk mengetahui tingkat pencapaian tujuan pembelajaran, dan sebaliknya tujuan pembelajaran menjadi parameter dalam perencanaan dan pengembangan evaluasi.

Demikian pula strategi pembelajaran dengan evaluasi memiliki hubungan fungsional dan timbal balik pula. Hubungan fungsional antara strategi dengan evaluasi tersebut bertolak dari fakta bahwa strategi pembelajaran aktualisasinya berupa serangkaian proses yang berfungsi sebagai wahana untuk pencapaian tujuan. Untuk mengetahui efektivitas dan efisiensi fungsi tersebut, diperlukan alat pengukur yakni evaluasi. (Supriadi Saputro, 2000: 29-31)

Hubungan fungsional dan timbal balik antara tujuan, strategi, dan evaluasi tersebut di atas dapat dilihat pada skema berikut:

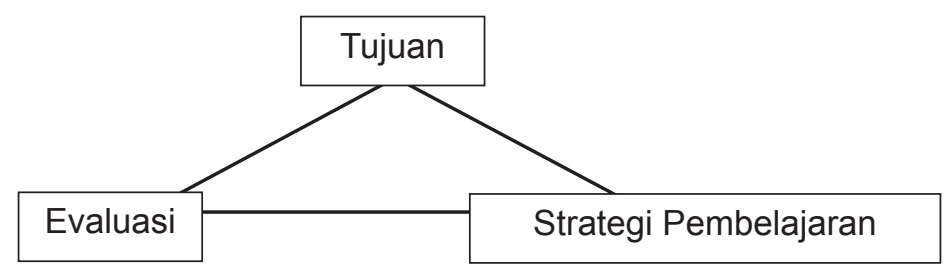

\section{Aplikasi Strategi Dalam Pembelajaran}

Pada dasarnya tahap-tahap kegiatan mengajar itu mencakup persiapan, pelaksanaan, evaluasi dan tindak lanjut. Sebetulnya strategi bclajar mengajar meliputi seluruh kegiatan/tahapan-tahapan tersebut, tetapi titik beratnya berada (terutama) di tahap persiapan.

a. Persiapan pengajaran

1). Perumusan tujuan pengajaran

Rumusan tujuan pengajaran merupakan pernyataan tentang apa yang diharapkan untuk diketahui, dilakukan dan dihayati oleh siswa seteiah menyelesaikan suatu kegiatan belajar. Kemampuan yang diperoleh sebagai hasil mengikuti pengalaman belajar, pada hakikatnya perubahan tingkah laku yang dapat diukur atau 
sekurang-kurangnya ada sesuatu yang dapat dijadikan indikator terjadinya perubahan.

Dengan demikian, menurut Muhaimin dkk. "merumuskan bahawa tujuan yang akan dicapai adalah merupakan aspek terpenting yang harus diperhatikan dalam mengajar". (Muhaimin, 1996: 78)

2). Pengembangan alat evaluasi

Untuk mengukur keberhasilan pencapaian tujuan pengajaran, disusun alat evaluasi yang sesuai dengan perubahan tingkah iaku. Pada tahap ini dirancang alat evaluasi yang akan digunakan seperti tes lisan, tertulis, perbuatan dan Iain-lain.

3). Analisis tugas belajar dan identifikasi kemampuan siswa

Kemampuan yang ingin dicapai sebagai tujuan pengajaran, diurai (dianalisis) atas unsur-unsur tingkah laku yang membentuk kemampuan tersebut. Unsur-unsur yang telah diidentifikasi tersebut diseleksi sehingga unsur-unsur yang belum dikuasai sejalah yang dipilih sebagai bahan pelajaran.

Pada tahap ini juga diidentifikasi karakteristik individual siswa seperti: kecerdasan/bakat, kebiasaan belajar, motivasi belajar, kemampuan awal dan kebutuhan belajar siswa, terutarna yang menyangkut kesulitan belajarnya.

4). Penyusunan strategi belajar mengajar

Strategi belajar mengajar pada hakikatnya adalah rencana kegiatan belajar mengajar yang dipilih oleh guru dalam rangka usaha pencapaian tujuan pengajaran yang telah disiapkan. Kriteria yang biasa dipakai dalam memilih strategi adalah: efisiensi, efektivitas dan keterlibatan siswa.

b. Pelaksanaan belajar mcngajar

Tahap ini merupakan pelaksanaan strategi belajar mengajar yang telah dipersiapkan pada tahap sebelumnya:

1. Pengelolaan kelas: klasikal, kelompok, tim atau yang lainnya. Terrnasuk pengaturan tempat duduk.

2. Penyelenggaraan tes untuk memperoleh balikan mengenai 
penguasaan siswa tentang bahan pelajaran terdahulu yang ada hubungannya dengan pelajaran baru.

3. Penyajian bahan pelajaran sesuai dengan metode dan teknik penyajian yang dikemukakan dalam strategi pembelajaran.

4. Pemberian motivasi dan penguatan.

5. Monitoring proses belajar mengajar.

c. Evaluasi hasil dan program belajar

Tahap kegiatan ini dimaksudkan untuk memperoleh balikan tentang hal-hal berikut:

1. Taraf pencapaian tujuan pengajaran.

2. Kesesuaian antara metode dan teknik pengajaran dengan sifat bahan pelajaran, tujuan yang ingin dicapai, karakteristik siswa dan kemampuan dasar siswa.

3. Keberhasilan program dalam mencapai tujuan program.

4. Keseksamaan alat evaluasi yang digunakan dengan tujuan pengajaran/tujuan program yang ingin dinilai keberhasilannya.

d. Perbaikan program kegiatan belajar mengajar (tindak lanjut)

Bagi siswa yang gagal mencapai tingkat keberhasilan yang telah ditetapkan, perlu diselenggarakan pengajaran remedial mengenai aspekaspek, pokok-pokok bahasan dari tugas belajar dan tujuan pengajaran yang belum dikuasai.

\section{Penggunaan Taksonomi Bloom Dalam Perumusan Tujuan Pembelajaran}

Dalam merumuskan tujuan-tujuan tersebut, khususnya tujuan instruksional ada dua pandangan yang dapat dijadikan pegangan. Pertama, bahwa suatu tujuan harus dirumuskan secara perilaku atau behavioral dan karena tujuan tersebut behavioral objectives (Bloom, Kratewoll, 1956, Kratewoll dan kawan-kawan 1969; dan Simpson: 1972). Rumusan ini menekankan pada kekhususan, keterukuran dan ketermatian. Kedua, bahwa tujuan tidak harus dirumuskan dan diukur secara parsial tetapi dalam satu kesatuan atau juga disebut expressive objectives (Eisner, 1972; 
Stenhouse 1975). Karena itu di Indonesia paling banyak adalah yang pertama yaitu behavioral objectives. (Harjanto, 2003: 59)

Menurut Bloom dkk, Taksonomi terbagi menjadi tiga ranah yaitu ranah Kognitif (penalaran), ranah Afektif (nilai dan sikap) dan ranah Psikomotorik (keterampilan gerak fisik).

\section{Ranah Kognitif}

Ranah Kognitif mempunyai enam sub yang disusun mulai dengan yang paling sederhana sampai tahap yang paling kompleks dan secara singkat, yaitu:

1. Pengetahuan (knowledge) yaitu kemampuan untuk mengingat bahan-bahan yang pernah dipelajari terdahulu.

2. Pemahaman (compherehension) yaitu kemampuan untuk menangkap pengertian dari sesuatu, seperti tnenerjemahkan sesuatu atau menafsirkan sesuatu dengan cara menjelaskan.

3. Penerapan (application) yaitu kemampuan untuk menggunakan bahan-bahan yang telah dipelajari dalam situasi yang baru dan kongkret atau nyata.

4. Penguraian (analysis) yaitu kemampuan untuk memilah-milih sesuatu bahan pada bagian-bagian koraponennya sehingga struktur bahan tersebut dapat dipahami.

5. Penyatuan (synthesis) yaitu kemampuan untuk menyatukan bagian-bagian yang terpisah guna membangun suatu keseluruhan yang utuh.

6. Penilaian (evaluation) yaitu mernutuskan atau menentukan nilai suatu materi untuk suatu tujuan yang telah ditentukan. (Harjanto, 2003: 60)

Gambar 1. Kesatuan dan saling berkaitan antar sub-ranah dalam ranah kognitif
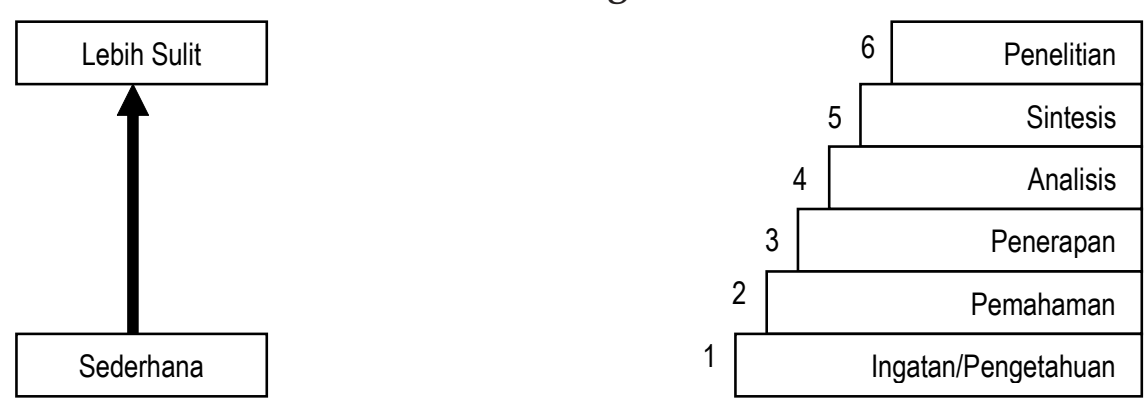


\section{Ranah Afektif}

Ranah Afektif ini dibagi menjadi lima level belajar yang disusun mulai dari yang paling sederhana sampai tahap yang paling kompleks dan secara singkat, yaitu:

1. Penerimaan (receiving) yaitu kesediaan seseorang atau mahasiswa untuk mengikuti suatu peristiwa tertentu, seperti kegiatan di dalam kelas, buku teks, musik dan Iain-lain.

2. Pemberian Tanggapan (responding) yaitu menunjuk pada keikutsertaan secara aktif dari mahasiwa atau siswa agar dapat memberikan reaksi kesiapan dalam memberikan respon atau minat.

3. Penentuan Sikap (value) yaitu berhubungan dengan nilai yang melekat pada mahasiwa atau siswa terhadap suatu peristiwa atau tingkah laku, seperti ingin meningkatkan keterampilan kelompok.

4. Pengorganisasian (organization) yaitu menggabungkan beberapa nilai yang berbeda-beda serta membangun sistem yang konsisten secara internal.

5. Pembentukan Lebih Sulit (characterization by a value or a complex) yaitu menunjuk pada proses afeksi di mana seseorang memiliki suatu sistem nilai sendiri yang mengendalikan perilakunya untuk waktu yang lama dan pada gilirannya akan membentuk gaya hidupnya. (Hisyam Zaini, 2002 : 74-76)

Gambar 2. Kesatuan dan saling berkaitan antar sub-ranah dalam ranah afektif
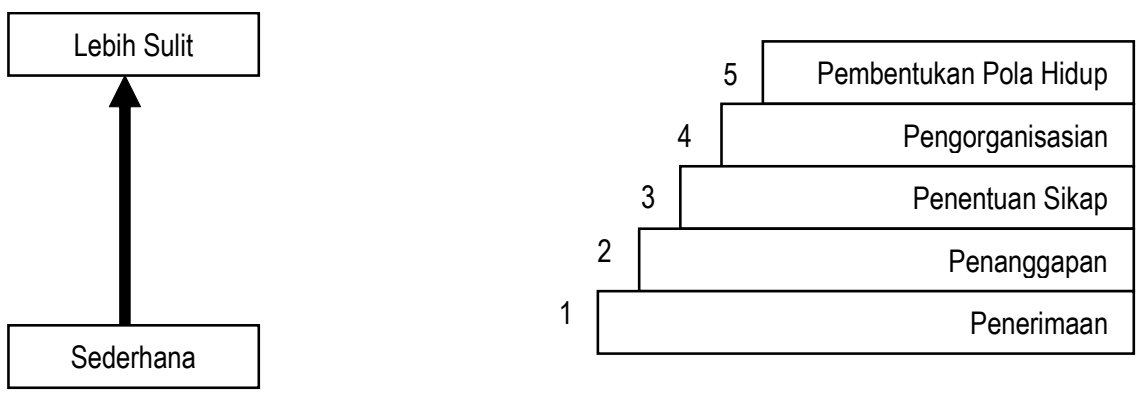


\section{Ranah Psikomotorik}

Ranah Psikomotorik ini dibagi menjadi tujuh level belajar yang disusun mulai dari yang paling sederhana sampai tahap yang paling kompleks dan secara singkat, yaitu:

1. Persepsi (perception) yaitu berkenaan dengan penggunaan organ-indra untuk menangkap isyarat yang membimbing aktivitag gerak.

2. Kesiapan (set) yaitu menunjukkan pada kesiapan untuk melakukan tindakan atau kesiapan mental dan fisik untuk bertindak.

3. Gerakan Terbimbing (guided respons) yaitu tahapan awal dalam mempelajari keterampilan yang kompleks seperti peniruan

4. Gerakan Terbiasa (mechanism) yaitu berkenaan dengan kinerja di mana respon mahasiswa atau siswa telah menjadi terbiasa dan gerakan-gerakan dengan penuh keyakinan dan kecakapan.

5. Gerakan Kompleks (complex overt respons) yaitu merupakan gerakan yang sangat terampil dengan pola-pola gerakan yang sangat kompleks.

6. Penyesuaian Pola Gerakan (adaptation) yaitu berkenaan dengan keterampilan yang dikembangkan dengan baik sehingga seseorang dapat memodifikasi pola-pola gerakan untuk menyesuaikan tututan tertentu atau menyesuaikan situasi tertentu.

7. Kreativitas (organitation) yaitu menujuk kepada pencitaan pola-pola gerakan baru untuk menyesuaikan situasi tertentu atau problem khusus. (Harjanto, 2003: 61)

Gambar 3: Kasatuan dan saling berkaitan antar sub-ranah dalam ranah Psikomotorik
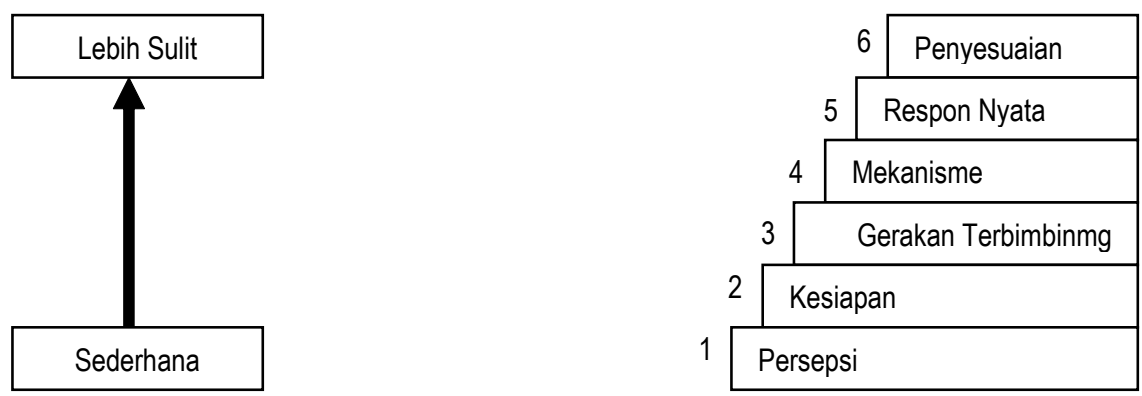

Kasatuan dan saling berkaitan antar sub-ranah 
Tabel 1 Fungsi Pengembangan Kognitif Siswa (Muhibbin Syah, 1999 : 53)

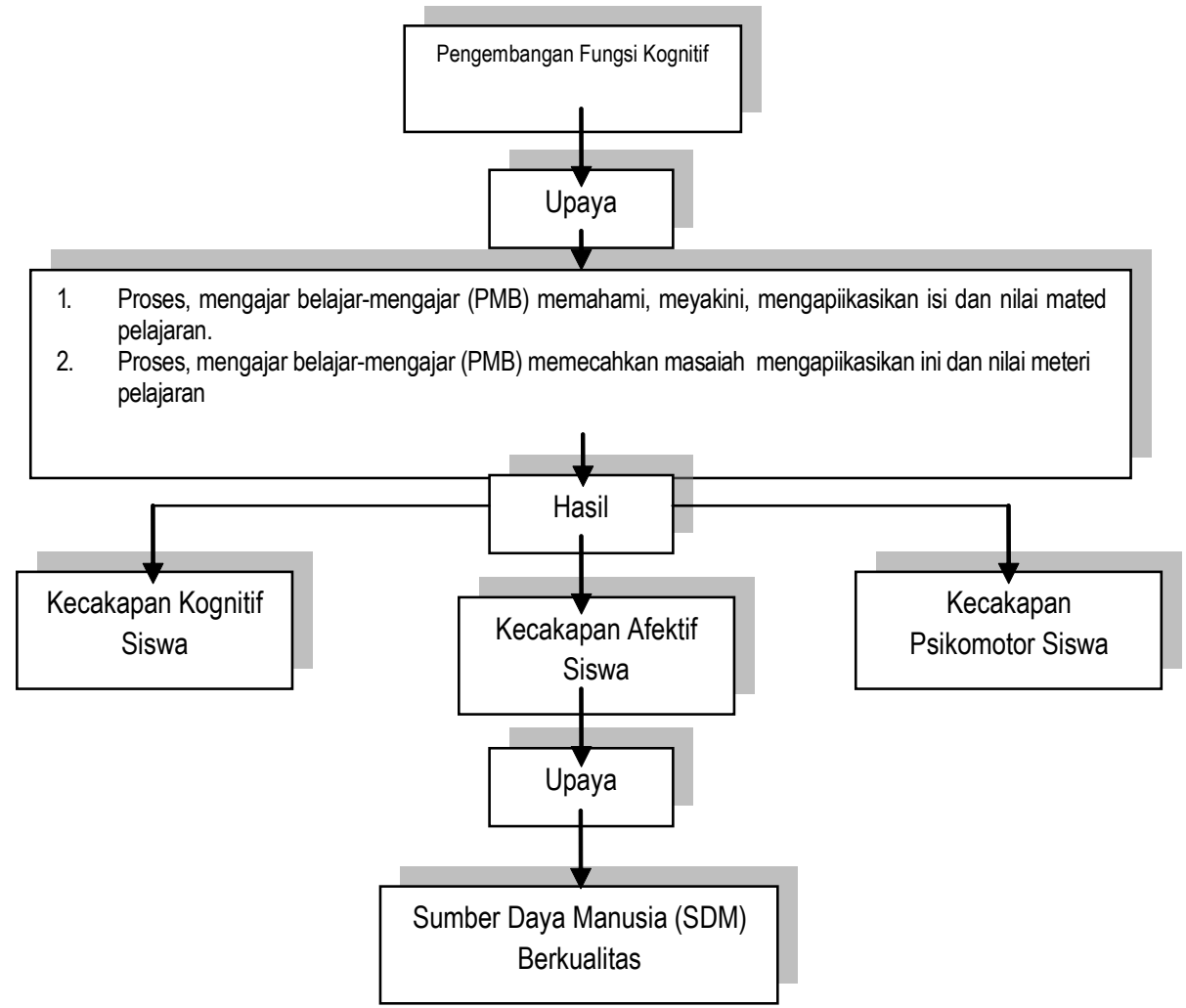

\section{E. Alasan Perlunya Merumskan Tujuan Pembelajaran}

Ada empat dasar pemikiran yang berkaitan dengan alasan perlunya merumuskan tujuan belajar atau pembelajaran, yaitu sebagai berikut:

a. Untuk memfokuskan pengajar terhadap apa yang seharusnya diajarkan dan untuk menghindari pemberian materi yang tidak relevan.

b. Untuk memfokuskan mahasiswa terhadap apa yang harus dipelajari (menghindari mempelajari materi yang tidak relevan)

c. Untuk menetukan metode yang lebih disukai atau cocok untuk pengajaran.

d. Untuk memfokuskan bahan ujian dan membantu untuk pemiliahan 
tes atau item tes yang terbaik yang akan menggambarkan tujuan dari pelaksanaan pembelajaran.

Berkaitan dengan itu, Meger mengemukakan tiga alasan pokok mengapa objective itu penting, yaitu sebagai berikut:

a. Dasar bagi perencanaan mata kuliah.

b. Memberikan kesempatan untuk mengevaluasi hasil.

c. Memberikan arah yang jelas bagi mahasiswa. (Margareth E. Bell Gredler, 1991 : 56)

\section{F. Ruang Lingkup Strategi Pembelajaran}

C.I. Tahap-tahap Pengelolaan Dan Pelaksanaan Strategi Pembelajaran.

Tahap-tahap pengelolaan dan pelaksanaan strategi pembelajaran dapat diperinci sebagai berikut:

1.a. Perencanaan, meliputi:

a. Menetapkan apa yang mau dilakukan, kapan dan bagaiman cara melakukannya.

b. Membatasi sasaran dan menetapkan pelaksanaan kerja untuk mencapai hasil secara maksimal melalui proses penentuan target.

c. Mengembangkan alternatif-alternatif.

d. Mengumpulkan dan menganalisis informasi.

e. Mempersiapkan dan mengkomunikasikan rencana-rencana serta keputusan-keputusan.

l.b. Pengorganisasian

a. Menyediakan fasilitas, perlengkapan dan tenaga kerja yang diperlukan untuk menyusun kerangka yang efisien dalam melaksanakan rencana-rencana melalui proses penetapan kerja yang diperlukan untuk menyelesaikannya.

b. Pengelompokan komponen kerja ke dalam struktur organisasi secara teratur

c. Membentuk wewenang dan mekanisme koordinasi.

d. Merumuskan serta menetapkan metode dan prosedur. 
e. Memilih, mengadakan penelitian dan pendidikan tenaga kerja serta mencari sumber-sumber lain yang diperlukan.

\section{I.c. Pengarahan}
a. Menyusun kerangka waktu dan biaya secara terperinci.
b. Memprakarsai dan menampilkan kepemimpinan dalam
c. Mengeluarkan instruksi-instruksi yang spesifik.
d. Membimbing, memotivasi dan melakukan supervisi.

\section{l.d. Pengawasan}
a. Mengevaluasi pelaksanaan kegiatan dibandingkan dengan rencana.
b. Melaporkan terhadap penyimpangan untuk tindakan koreksi dan merumuskan tindakan koreksi, menyusun standar- standar dan saran-saran.
c. Menilai pekerjaan dan melakukan koreksi terhadap penyimpangan-penyimpangan. (Suharyono, 1991: 27)

\section{C.2. Strategi Pembelajaran}

\section{2.a. Ceramah}

Ceramah dalam dunia pendidikan, khususnya di Indonesia sangat terkenal dengan kepopulerannya, baik di madrasah maupun di perguruan tinggi. Karena ceramah adalah salah satu dari metode pembelajaran yang dilakukan dengan menyampaikan pesan informasi melalui lisan. (Hisyam Zaini, 2002 : 131) Namun metode ceramah juga mempunyai segi positif dan segi negatifnya. (Abu AhmadI, dan Joko Tri Prasetya, 1997: 53)

\section{2.a.l. Segi Positif}

a. Dalam waktu yang singkat guru atau dosen dapat menyampaikan bahan pelajaran sebanyak-banyaknya.

b. Organisasi kelas lebih sederhana, tidak perlu mengadakan pengelompokan.

c. Guru mampu menguasai kelas dengan mudah, walaupun jumlah pesertanya cukup banyak. 
Mohammad Asrori - Pengertian, Tujuan dan Ruang Lingkup Strategi ...

d. Guru sebagai penceramah dengan hasil yang baik, maka dapat menimbulkan semangat dan kreasi yang konstruktif.

e. Fleksible

l.a.l. Segi Negatif

a. Guru atau Dosen sulit untuk mengetahui pemahaman anak didik terhadap bahan-bahan yang telah diberikan.

b. Kadang-kadang guru ingin menyampaikan bahan-bahan sebanyak-banyaknya hingga menjadi bersifat pemompahan.

c. Anak didik cenderung menjadi pasif dan ada kemungkinan kurang tepat dalam mengambil kesimpulan, karena guru menyampaikan dengan lisannya saja.

d. Jika guru tidak memperhatikan dari segi psikologis anak didik, maka metode ceramah dianggap membosankan, begitu juga sebaliknya.

2.b. Diskusi

Diskusi adalah suatu kegiatan kelompok dalam memecahkan sebuah permasalahan untuk menarik kesimpulan. Diskusi tidak sama dengan berdebat, karena diskusi selalu diarahkan kepada pemecahan sebuah masalah (Abudin Nata, 1997: 107) yang menimbulkan berbagai macam pendapat dan akhirnya diambil satu kesimpulan. Namun metode diskusi juga mempunyai segi positif dan segi negatifnya. (Abudin Nata, 1997: 5)

2.b.1. Segi Positif

a. Suasana kelas akan bertambah hidup.

b. Dapat menaikkan prestasi kepribadian, baik dari segi individu seperti tolerasi, demokratis, kritis, berfikir sistematis dan sebagainya.

c. Kesimpulan-kesimpulan diskusi akan mudah dipahami anak karena mengikuti proses berpikir sebelum diambil sebuah kesimpulan.

d. Peserta didik belajar mematuhi peraturan-peraturan atau tata tertlb dalam suatu musyawarah sebagai latihan pada musyawarah yang sebenarnya. 


\section{2.b.2. Segi Negatif}

a. Kemungkinan juga ada peserta didik yang tidak aktif, sehingga diskusi merupakan kesempatan untuk melepaskan diri dari tanggung jawab.

b. Sulit menduga hasil yang akan dicapai, karena waktu yang digunakan untuk berdiskusi terlalu panjang.

2.c. Tanya Jawab

Metode tanya jawab adalah suatu metode yang sering kali digunakan oleh guru dalam dunia pendidikan, dimana seorang guru bertanya para murid, dan murid menjawab tentang bahan materi yang ingin diperolehnya. Namun metode tanya jawab juga mempunyai segi positif dan segi negatifnya. (Abudin Nata, 1997: 56)

2.c.l. Segi Posistif

a. Kelas akan hidup karena anak didik aktif berpikir dan menyampaikan pikiran melalui berbicara.

b. Baik sekali untuk melatih anak didik agar berani berbicara.

c. Timbulnya perbedaan pendapat oleh guru, anak didik akan membawa ke suasana diskusi.

2.C.2. Segi Negatif

a. Apabila terjadi perbedaan pendapat akan banyak waktu untuk menyelesaikannya.

b. Kemungkinan akan terjadi penyimpangan terhadap anak didik terutama apabila terdapat jawaban-jawaban yang kebetulan menarik perhatiannya, tetapi bukan sasaran yang dituju.

c. Dapat menghambat cara berpikir, apabila seorang guru kurang pandai dalam penyajian materi pelajaran.

d. Situasi persaingan akan bisa timbul, apabila guru kurang menguasai teknik pemakaian metode ini.

\section{2.d. Demonstrasi dan Eksperimen}

Strategi pembelajaran melalui metode demonstrasi adalah metode mengajar, di mana seorang guru atau orang lain yang sengaja diminta atau murid sendiri memperlihatkan kepada seluruh kelas suatu proses, misalnya proses mengambil air wudlu, prosesi sholat dan lain sebagainya. 
Ekesperimen adalah metode pengajaran di mana seorang guru dan murid bersama-sama mengerjakan sesuatu sebagai latihan praktis dari apa yang telah diketahui, misalnya murid merawat jenazah dan lain sebagainya. Namun metode demonstrasi dan eksperimen juga mempunyai segi positif dan segi negatifnya. (Abudin Nata, 1997: 62-63)

\section{2.d.l. Segi Positif}

a. Perhatian anakakan terpusat kepada apa yang didemonstrasikan dan memberikan kemungkinan berpikir kritis.

b. Memberikan pengalaman praktis yang dapat membentuk perasaan dan kemauan anak.

c. Akan mengurangi kesalahan dalam mengambil sebuah kesimpulan, karena anak didik mengamati langsung terhadap suatu proses.

d. Dengan metode ini masalah-masalah yang mungkin timbul dalam hati anak didik dapat terjawab.

\section{2.d.2. Segi Negatif}

a. Dalam melaksanakan metode demonstrasi memerlukan waktu yang cukup lama.

b. Apabila kekurangan alat-alat peraga, maka metode ini juga kurang efektif.

c. Metode ini sukar dilaksanakan apabila anak didik belum matang untuk melaksanakan eksperimen

d. Banyak alat-alat yang tidak didemonstrasikan karena besarnya alat.

\section{G. Kesimpulan}

1. Proses belajar mengajar konvesional umumnya berlangsung satu arah yang merupakan proses transfer atau pengalihan pengetahuan, informasi, norma, nilai, dan lain-lainnya dari seorang guru atau dosen kepada peserta didik, murid atau mahasiswa. Proses seperti itu dibangun atas dasar anggapan bahwa siswa atau peserta didik ibarat bejana kosong atau kertas putih. Guru, dosen atau pengajarlah yang harus mengisi bejana tersebut atau menulis apapun di kertas putih tersebut. 
2. Paradigma muncul, karena tidak lagi melihat siswa, murid, mahasiswa, peserta didik atau warga belajar sebagai bejana kosong atau seperti kertas putih. Pandangan ini menganggap bahwa peserta didik, warga belajar, terutama orang dewasa, sebagai manusia yang yang memiliki pengalaman, pengetahuan, perasaan, keyakinan, cita-cita, kesenangan dan keterampilan. Maka dari itu sangat perlu pengalaman mereka harus kita hargai dan diangkat dalam proses dan aktivitas pembelajaran di kelas. Hal ini juga berimplikasi terhadap perlunya strategi pembelajaran yang interaktif baik antara mahasiswa dengan dosen maupun antar mahasiswa.

3. Dengan demikian, strategi pembelajaran yang tepat akan membina peserta didik untuk berpikir mandiri, kreatif dan sekaligus adaptif terhadap berbagai situasi yang terjadi dan yang mungkin akan terjadi. Oleh karena itu, ketika mempersiapkan perkuliahan, dosen atau guru harus memikirkan cara yang tepat, agar mahasiswa, peserta didik, warga belajar mampu memproses informasi yang telah disampai oleh guru, dosen atau para pengajar.

\section{DAFTAR PUSTAKA}

Ahmadi, Abu. dan Tri Prasetya, Joko, 1997. Strategi Belajar Mengajar, Bandung : CV. Pustaka Setia, Cet. I.

Barnadib, Imam Sutari, 1993. Pengantar Ilmu Pendidikan Sistematis. Yogyakarta : Andi Ofset, Cet. XIV.

Gredler, Margareth E. Bell. 1991. Belajar dan Membelajarkan. Terj : Munandir, Jakarta: Rajawali Press.

H. Nata, Abudin, 1997. Filsafat Pendidikan Islam, Jakarta: Logos Wacana Ilmu, Cet. I.

H. Ni'am, M. Asrorun, 2006. Membangun Profesionalitas Guru, Jakarta : eLSAS, Cet. I.

Harjanto, 2003. Perencanaan Pengajaran, Jakarta : PT. Rineka Cipta, Cet. III.

Indra Jati, Sidi, 2001. Menuju Masyarakat Belajar ; Menggagas Paradigma Pendidikan, Jakarta : Logos, Cet. I. 
Mohammad Asrori - Pengertian, Tujuan dan Ruang Lingkup Strategi ...

Jamrah, Syaiful Bahri dan Zain, Aswan, 1996. Strategi Belajar Mengajaar. Jakarta: Rineka Cipta.

Mansyur, 1991. Strategi Belajar Mengajar, Jakarta : Universitas Terbuka.

Marimba, Ahmad D, 1962. Pengantar Filsafat Pendidikan Islam, Bandung : PT. Al-Ma'arif.

Muhaimin dkk., 1996. Strategi Belajar Mengajar (Penerapannya dalam Pembelajaran Pendidikan Agama), Surabaya: Citra Media.

Partanto, Pius A dan Al Barry, M. Dahlan, 2001. Kamus Ilmiah Populer. Surabaya: Arloka.

Ramayulis, 1998. Ilmu Pendidikan Islam, Jakarta : Kalam Mulia, Juli, Cet. II.

Rohani Ahmad dan Ahmadi, Abu. Pengelolan Pembelajaran. Jakarta: Rineka Cipta.

Sadirman, Arief S. dkk., 1996. Media Pendidikan, Jakarta : PT Raja Grafmdo Persada, ed. I, Cet. IV.

Saputro, Supriadi dkk. 2000. Strategi Pembelajar, Bahan Sajian Prograam Pendidikan Mengaajar. Malang: Universitas Negeri Malang.

Slameto, 1991. Proses Belajar Mengajar dalam Sistem Kredit Semester. Jakarta: Bumi Aksara.

Suharyono, dkk. 1991. Strategi Belajar Mengajar 1, Semarang : IKIP Semarang Press.

Sujiono, Anas, 2001. Pengantar Evaluasi Pendidikan, Jakarta : PT. Raja Grafmdo Persada, Agustus, Cet. III.

Syah, Muhibbin, 1999. Psikologi Belajar. Jakarta : Logos, Cet. I.

Syah, Muhibbin, 2003. Psikologi Pendidikan dengan Pendekaatan Baru. Bandung: Remaja Rosda Karya.

Zaini, Hisyam. dkk. 2002. Desain Pembelajaran di Perguruan Tinggi, Yogyakarta: CTDS IAIN Sunan Kalijaga. 